\title{
Hempcrete Buildings: Environmental Sustainability and Durability of Two Case-Studies in North and South Italy
}

\author{
Giovanni Dotelli ${ }^{1}$, Chiara Moletti ${ }^{1}$, Patrizia Aversa $^{2}$, Sergio Sabbadini ${ }^{3}$, Anna Marzo ${ }^{4}$, \\ Concetta Tripepi ${ }^{4}$, Pasqua Lauriola ${ }^{5}$ and Vincenza A.M. Luprano ${ }^{2}$ \\ ${ }^{1}$ Politecnico di Milano, Dip. Chimica, Materiali e Ingegneria Chimica "G.Natta", p.zza L. da Vinci \\ 32,20133 Milano, Italy, giovanni.dotelli@polimi.it \\ ${ }^{2}$ ENEA C.R. Brindisi - SS 7 km 706 - Brindisi, Italy \\ ${ }^{3}$ Politecnico di Milano, Dip. Architettura e Studi Urbani, p.zza L. da Vinci 32, 20133 Milano, Italy 4 \\ ${ }^{4}$ ENEA C.R. Bologna - Via Martiri Monte Sole, 4 - Bologna, Italy \\ ${ }^{5}$ Private Architecture Studio
}

\begin{abstract}
In the framework of Circular Economy policies aimed at reducing the consumption of raw materials, shives, as an agricultural by-product of hemp cultivation, have gained a renovated life in the construction sector. Its excellent thermal insulating properties permitted the development of new building materials to be used in various executive technologies. When shives are mixed with a mineral binder such as lime or cement, the mixture is usually referred to as hempcrete. In Italy, the use of hempcrete and the development of new production chains and implementation techniques dates back only to about the last decade, while other European countries have more long-lasting experiences $(90 s)$. In order to assess the potential benefits of hempcrete in the construction sector, its environmental performances were evaluated using the LCA methodology, by comparing four non-loadbearing representative walls, one made with hempcrete blocks and the others with more "traditional" materials. This research constitutes a solid basis for the development of future guidelines and/or regulations at national and international level in order to guarantee the maximum diffusion of this type of product. Then, a study has been carried out regarding the functionality of hempcrete blocks in masonry, layered with finishing plaster made of fine hemp shives, to evaluate the in-situ hygrothermal building performance. In particular, measurement methods were developed and analysis were carried out on two houses, one in northern Italy and one in southern Italy, and precisely in Sicily, focusing the study on the performances of the walls subjected to warm Mediterranean climates. Indeed, the literature on masonry behavior in hot Mediterranean climates is much scarcer than in cold climates.
\end{abstract}

Keywords: Hempcrete, Hygrothermal Behaviour, Sustainable Materials, Mediterranean Climate, Durability.

\section{Introduction}

The building sector has a major impact on the natural environment, so sustainable building materials have been developed to reduce the emission into the atmosphere of carbon dioxide and polluting gasses typical of the process of production of traditional building materials. Among sustainable materials, the nature-based solutions are carbon negative and characterized by low-embodied energy (Murphy and Norton, 2008; Ip and Miller, 2012); in addition, they are able to improve the performances of a building envelope because of their remarkable insulating properties. 
Many bio-composite materials are produced introducing biomasses, residual of agricultural cultivation (e.g. hemp, straw, rice-husk), into traditional binders (e.g. lime, concrete). In this way, the new building materials exploit natural resources that would otherwise be wasted, being the byproduct of agricultural activities (Liu et al., 2017).

This study focusses on hempcrete which is produced introducing hemp shives into an hydraulic binder. The increasing utilization of this material is due to its characteristic hygroscopic properties which determine an improvement of the indoor environmental comfort as reported, for example, by Nordby and Shea (2013). The present research aims to investigate the performances of walls built using hempcrete blocks. The bio-blocks are not- loadbearing and they are used to insulate thermally external or internal walls or to divide internal spaces. The prefabricated blocks production developed in order to solve some issues typical of casting of hempcrete in situ; especially the hardening step which is critical as it significantly influences the homogeneity of the properties in the casted material. Hence, by producing blocks, it is possible to control the hardening phase and to improve the quality of the material (Elfordy et al., 2008).

A preliminary evaluation of the environmental performances of a wall made with hempcrete blocks has been performed through LCA (Life Cycle Assessment) methodology according to EN ISO 14040-14044:2006 standards. A comparative assessment with different wall systems was started, preliminarily only at A1-A3 stages, i.e. product stage (EN 15804:2012+A2:2019).

Then, this research develops experimental methodologies to investigate the hygrothermal behaviour of hempcrete during its service life, so it would be possible to evaluate its durability

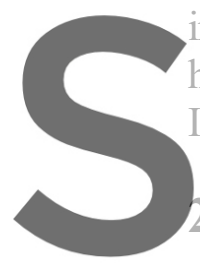
in situ. The measurements have been perf
hempcrete blocks in two residential houses in
Italy).
2 Durability of Hempcrete
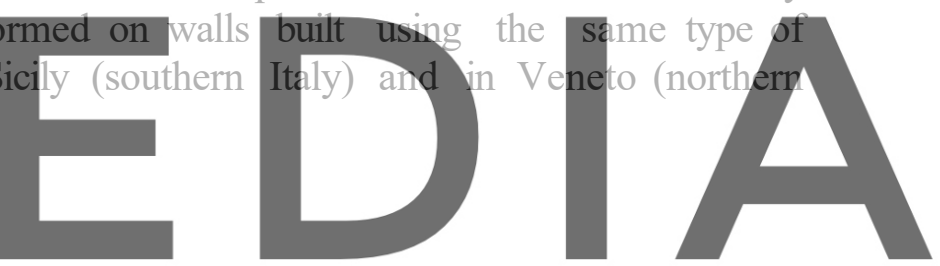

Durability has a crucial importance for building materials, few data exist about the durability of

Register fempreede an from 1990s and in Italy only from 2000s. The first data collected on buildings have given good results, comparable to the performances of traditional materials (Clarke, 2002). The aim of this project is to perform field test in the two selected buildings, both in Sicily and in Veneto, to obtain information about the behaviour of hempcrete blocks. This would support the users in the utilization of the material. The interesting results on the performances of the material presented in this paper will be implemented with periodical tests to study the evolution of the performances of the material and its durability in residential structures.

The main concern about the durability of hempcrete is determined by the presence of vegetal material because the variation of moisture conditions can cause its degradation. Thus, a decrease of the performances of hempcrete and, possibly, a reduction of the salubrity of the environment could occur. 
Data about the durability of hempcrete can be collected carrying out laboratory tests, some studies have simulated possible critical situations, typical of the service life, but field tests are recommended to increase the knowledge about the material. The effects of biological attack by bacteria or fungi have been studied by inoculating microorganisms into the material. Periodic measurements along two years have been carried out by Walker et al. (2014) after the abundant introduction of bacteria; the results show that microorganisms, even those able to live in alkaline conditions, did not proliferate and degradation did not occur. Moreover, the alternating high and low values of humidity, typical of Mediterranean climate, further limit their permanence into the material. The alternation of wet and dry periods is fundamental to avoid the biological degradation: high humidity favours the spread of fungi or bacteria on the surface of hempcrete reducing the hygrometric performances of the wall while low humidity allows the penetration of microorganisms inside the material reducing the water vapour permeability (Arizzi et al., 2016). The importance of testing even after several months is underlined by Marceau et al. (2017) who have found the conditions necessary for the mould growth: high relative humidity (around 98\%) and $\mathrm{pH}$ lower than 10. The $\mathrm{pH}$ of hempcrete decreases due to the carbonation process, for this reason a long-term monitoring would allow to investigate the behaviour of the material in critical conditions. Some biocide treatments as $\gamma$ irradiation of hemp shives, addition of anti-microbial or nanoparticles able to increase the resistance to bacteria or fungi have been proposed (Arizzi et al., 2016).

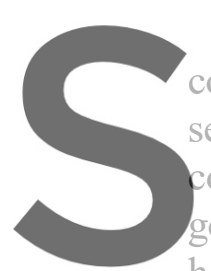

Beside the growth

consequently, the ther

selection of the protective

counter the biological d

good, no cracks or

hempcrete blocks, characterized ty
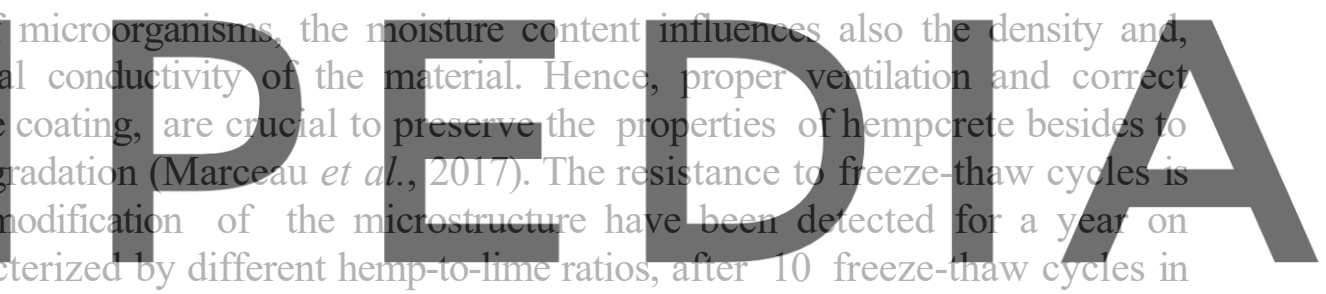

conditions near saturation (RH around 90\%). Carbonation reduces the vulnerability to freeze-

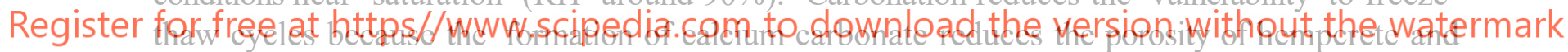

hence the amount of water absorbed (Walker et al., 2014). Furthermore, tests of exposure to salt

(NaCl) performed by Walker et al. (2014) and Arizzi et al. (2016) did not provoke degradation of blocks and no effloresce was detected. If salt precipitates on the surface, it is easily removed by rainfall while, if absorbed, the hygroscopic behaviour helps in weathering through natural wet-dry cycles. Therefore, the weathering of salt is less aggressive in hempcrete than in other inorganic porous materials (e.g. stone, mortar).

\section{Life Cycle Assessment}

In recent years, the interest for hemp-based building materials has increased also due to their expected positive environmental performances (Ingrao et al., 2015). However, few LCA 
studies have evaluated different hempcrete wall technologies: spray (Boutin et al., 2006; Pretot et al., 2014) sprayed hempcrete with timber frame support (Ip and Miller, 2012; Pretot et al., 2014) and blocks. A preliminary environmental assessment of the hempcrete technology is given here by evaluating a representative wall made with hempcrete blocks. Recently, the environmental performances of an Italian hempcrete block (Arrigoni et al., 2017) as well as hemp cultivation (Zampori et al., 2013) have been carried out.

In order to assess the environmental sustainability of hempcrete blocks used in non-load bearing walls, three additional alternatives have been selected and compared at the level of materials production (A1-A3, EN 15804:2012+A1:2019): masonry bricks, expanded clay bricks and aerated autoclaved concrete (AAC) blocks with cement-lime mortars. The comparison is based on $1 \mathrm{~m}^{2}$ of vertical non-load-bearing wall (Functional Unit). Data for alternative bricks are taken from Environmental Product Declarations (EPDs) of selected producers (Aversa et al., 2019; Margutti and Pennati, 2018). The impact categories selected are those reported in the EPDs and the method used to evaluate the environmental burden of the four walls is CML 2001 (Guinée and Lindeijer, 2002).

In Figure 1, the results of the four walls in seven impact categories are compared. The hempcrete wall solution has very positive performances in six out of seven impact categories. This preliminary LCA is highly promising, especially considering that only the first life cycle stages of the building are included in the analysis. Further benefits will certainly come from the use stage

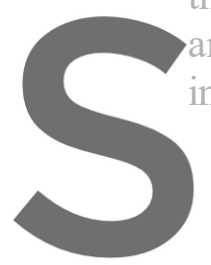

and end-of-life. Moreover

into account production in
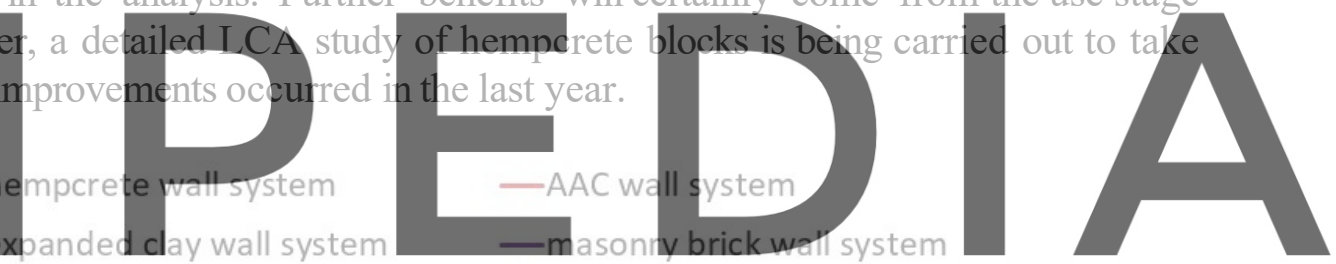

Register for free at https//www.scipedia.comAtoidłeranload the version without the watermark

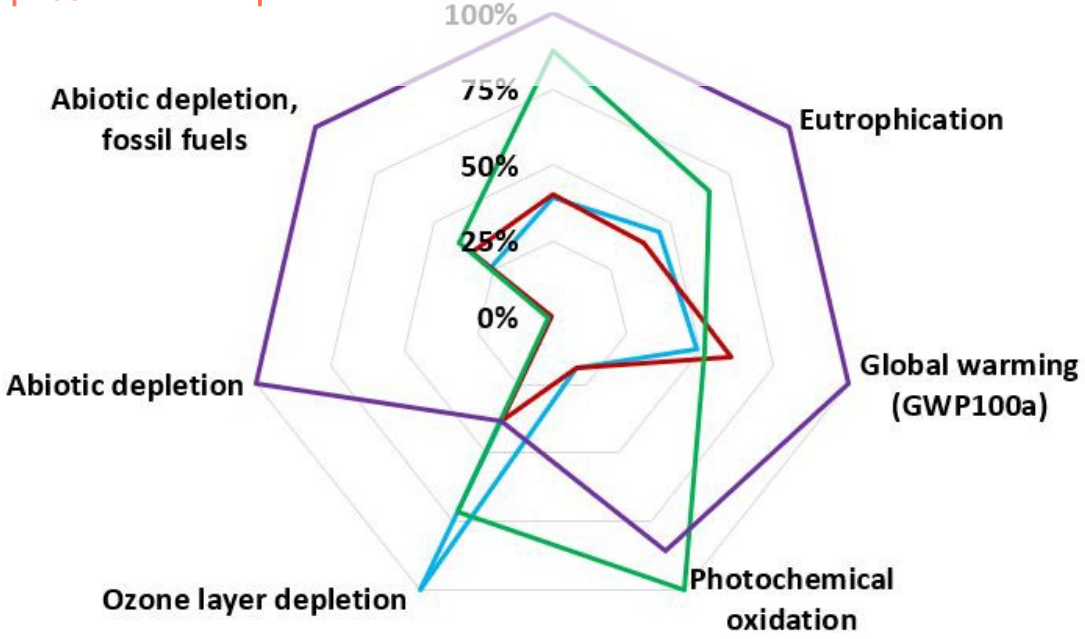

Figure 1. Wall system s comparative LCA assessment at the product stage A1-A3. 


\section{Case Study}

The experimental methodology to perform the field measurements that allow to determine the hygrothermal performances of hempcrete walls has been tested in laboratory on a $1 \mathrm{~m}^{2}$ wall, built in hempcrete blocks, introduced in a climatic chamber. Known temperature cycles have been applied to simulate hot temperate climates (Aversa et al., 2019). The test wall had been built employing the same type of blocks used in the perimeter walls of the detached houses in Sicily (Serradifalco, CL).

Currently, the data collected in the Sicilian campaign have been elaborated, the reference standards are UNI EN 15026:2008 and UNI EN ISO 13788:2013. The measurements have been performed on the South-West, South-East and North-West walls for 13 days (in August) during which the inhabitants where not present to exclude the influence of the air conditioning system. The wall system is $400 \mathrm{~mm}$ thick (Figure 2): the hempcrete blocks have a thickness of $360 \mathrm{~mm}$, the ratio between dolomitic lime and hemp shives is 3:1; the plaster is premixed, constituted by hydraulic lime NHL 5 and it has thickness of $20 \mathrm{~mm}$ both on the internal and on the external face of the walls. The bedding mortar is characterized by a dolomitic lime-to- hemp shive ratio of $3: 1$.
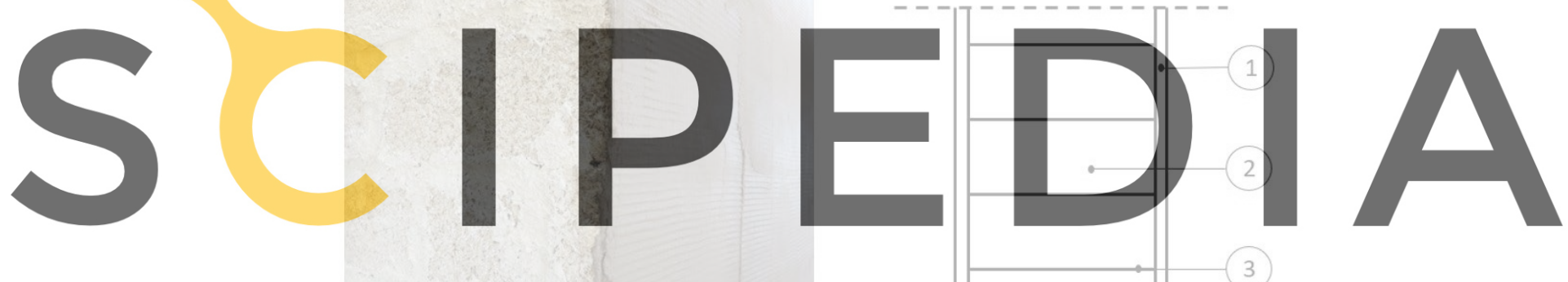

Register for free at https//www.scipedia.com to download the -version_without the watermark
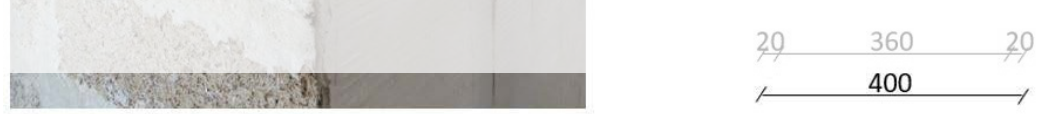

Figure 2. Wall system: 1-plaster(thickness: $20 \mathrm{~mm}$ ); 2-hempcreteblocks (thickness:360mm);3-bedding mortar.

Temperature and humidity sensors have been applied on the walls (see Aversa et al., 2019) while the outdoor weather conditions have been measured by a weather control unit. The temperature and humidity of internal and external surfaces of the North-West wall, detected during the period of analysis, are plotted in Figure 3.

Regarding the relative humidity, on the internal wall an average value of $67 \%$ has been measured while the external value shows variations in between $40 \%$ and $100 \%$, due to some rainy days during the monitoring period. Hence, the behaviour of the wall is good, the damping has been higher than $80 \%$. Also, the thermal response has been good, the average temperature measured on the internal wall has been $26^{\circ} \mathrm{C}$ (with variations of $\pm 1.5^{\circ} \mathrm{C}$ ) in 
response to the variations of external temperature between $15^{\circ} \mathrm{C}$ and $35^{\circ} \mathrm{C}$. Likewise humidity, the damping is higher than $80 \%$. The offset between internal and external humidity is of 6 hours, relatively to the maximum peak of humidity, while the offset was around 8 hours in laboratory tests (Aversa et al., 2019).

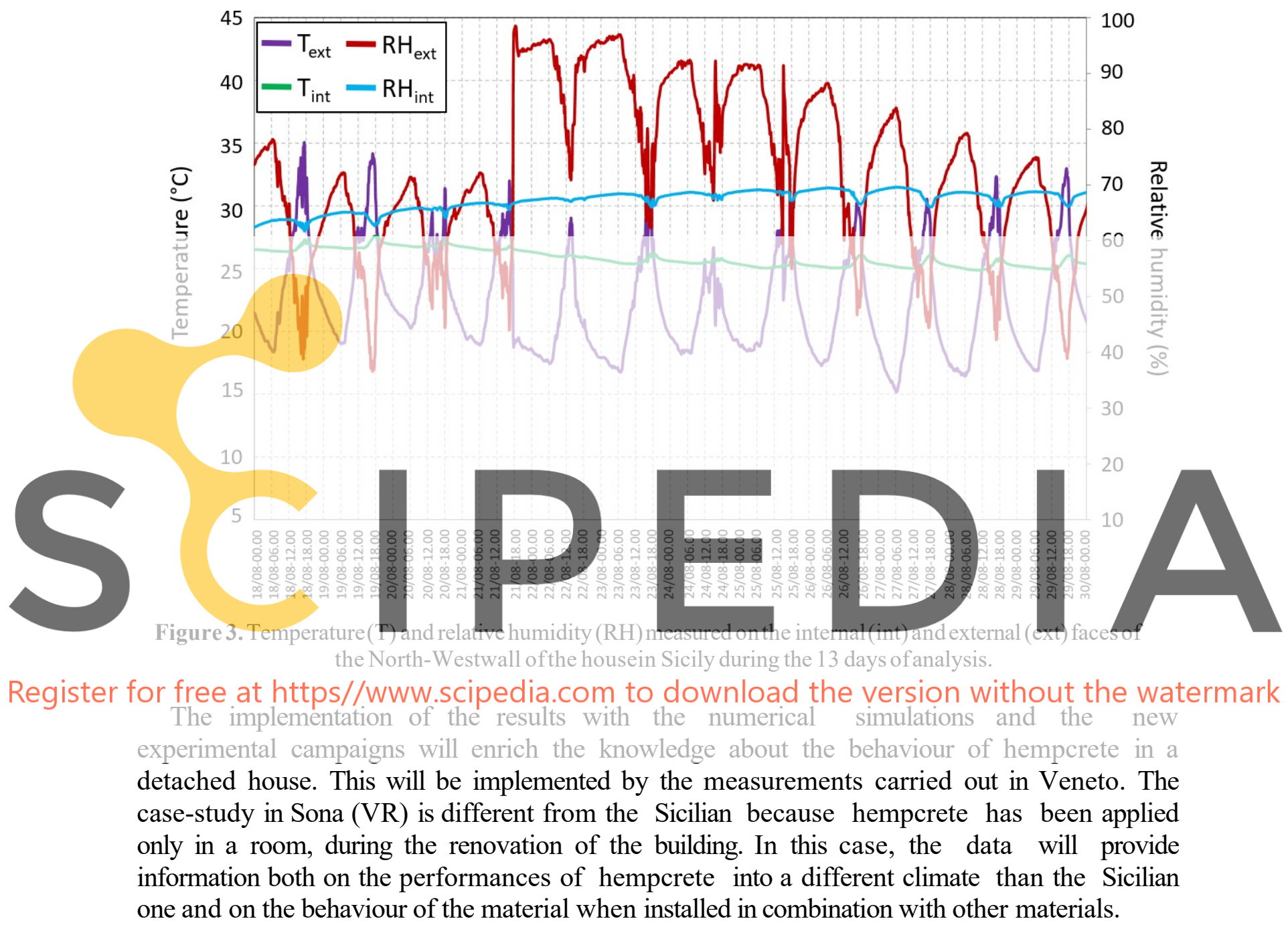

\section{Conclusions}

This study shows the promising performances of hempcrete blocks both in terms of environmental sustainability and hygrothermal properties. The preliminary environmental assessment through LCA is highly encouraging and seems to confirm what has been already 
demonstrated in the recent literature, i.e. that the use of hempcrete blocks has a beneficial effect on relevant impact categories. Furthermore, some of the advantages of the hempcrete are not clearly evidenced in the first life cycle stages of a building, in terms of energy saving and recyclability at the end-of-life.

The first evaluation of the hygrothermal performances of hempcrete blocks in the Sicilian climate is positive. The indoor temperature and humidity were almost constant during the analysis period without the utilization of ventilation, air-conditioning systems or air exchange. Further measurement in situ will allow to understand the evolution of the material performances in time. Thus, the durability of hempcrete will be evaluated together with the possibility to install it in place of traditional materials, especially when sudden climatic variations occur, or higher humidity and continuous rain conditions verify.

Moreover, the availability of residential houses for in situ measurements will allow the evaluation of energetic behaviour of the buildings and the evaluation of the environmental performances of the material when applied in construction works. Also, the effects on the indoor comfort will be investigated i.e. humidity and temperature of the internal spaces will be measured.

Acknowledgements

This study is based on PAR2017 Project (D.2 Nearly zero energy buildings (nZEB)) funded by Italian Ministry of Economic Development.

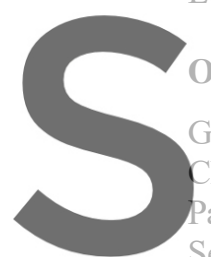

ORCID

Giovanni Dotelli: https://ordi

Chiara Moletti: https://orcid

Pergio Sabbadini: https://orcid.org/0000-0002-5848-9756
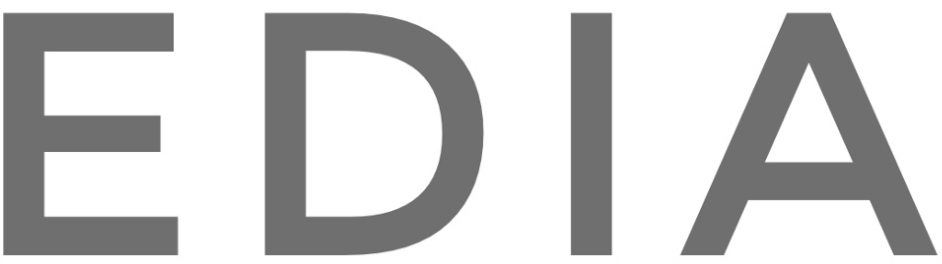

Anna Marzo: http://orcid.org/0000-0002-1469-0626

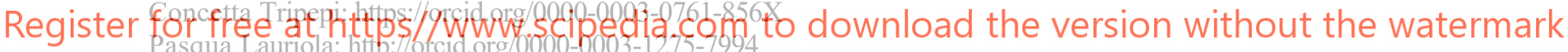

Vincenza A.M. Luprano: https://orcid.org/0000-0003-4942-3664

\section{References}

Arizzi, A., Viles, H., Martín-Sanchez, I. and Cultrone, G. (2016). Predicting the Long-TermDurability of Hemp- Lime Renders in Inland and Coastal Areas Using Mediterranean, Tropical and Semi-Arid Climatic Simulations. Science of the Total Environment, 542, 757-770. doi:10.1016/j.scitotenv.2015.10.141.

Arrigoni, A., Pelosato, R., Melià, P., Ruggieri, G., Sabbadini, S. and Dotelli, G. (2017). Life Cycle Assessment of Natural Building Materials: The Role of Carbonation, Mixture Components and Transport in the Environmental Impacts of Hempcrete Blocks. Journal of Cleaner Production, 149, 1051-1061. doi:10.1016/j.jclepro.2017.02.161.

Aversa, P., Daniotti, B., Dotelli, G., Marzo, A., Tripepi, C., Sabbadini, S., Lauriola, P. and Luprano, V. A.M. (2019). Thermo-Hygrometric Behavior of Hempcrete Walls for Sustainable Building Construction in the Mediterranean Area. IOP Conference Series: Earth and Environmental Science, 296(1). doi: 10.1088/17551315/296/1/012020.

Boutin, M.P., Flamin,C., Quinton, S. and Gosse, G. (2006). Study on the Environmental Characteristics of Hemp through the Analysis of its Life Cycle (in French). Ministry of Agriculture, Agrifood, and Forestry, Paris, France.

CEN (2019). EN 15804:2012 + A2:2019 Sustainability of construction works - Environmental product declarations Core rules for the productcategory of construction products. 
Gioavanni Dotelli, Chiara Moletti, Patrizia Aversa, Sergio Sabbadini, Anna Marzo, Concetta Tripepi, Pasqua Lauriola and Vicenza A.M. Luprano

CEN (2006). ENISO 14040: EnvironmentalManagement-Life Cycle Assessment-Principles andFramework.

CEN (2006). EN ISO 14044: Environmental Management - Life Cycle Assessment-Requirements and Guidelines. Clarke, S. (2002). Final Report on the Construction of the Hemp Houses at Haverhill, Suffolk. Suffolk. Building Research Establishment, Watford, (209), 209-717.

Elfordy, S., Lucas, F., Tancret, F., Scudeller, Y. and Goudet, L.(2008). Mechanicaland ThermalProperties of Lime and Hemp Concrete ('hempcrete') Manufactured by a Projection Process. Construction and Building Materials, 22 (10), 2116-2123. doi: 10.1016/j.conbuildmat.2007.07.016.

Guinée, J. B. and Lindeijer, E. (2002). Handbook on life cycle assessment: operational guide to the ISO standards. Netherlands: Springer Science \& Business Media.

Ingrao, C., Lo Giudice, A., Bacenetti, J., Tricase, C., Dotelli, G., Fiala, M., Siracusa, V. and Mbohwa, C. (2015). Energy and Environmental Assessment of Industrial Hemp for Building Applications: A Review. Renewable and Sustainable Energy Reviews, 51, 29-42. doi:10.1016/j.rser.2015.06.002.

Ip, K. and Miller, A. (2012). Life Cycle Greenhouse Gas Emissions of Hemp-Lime Wall Constructions in the UK. Resources, Conservation and Recycling, 69, 1-9. doi:10.1016/j.resconrec.2012.09.001.

Liu, L.F., Li, H. Q., Lazzaretto, A., Manente, G., Tong, C.Y., Liu, Q.B. and Li, N.P. (2017). The Development History and Prospects of Biomass-Based Insulation Materials for Buildings. Renewableand Sustainable Energy Reviews, 69, 912-932. doi:10.1016/j.rser.2016.11.140.

Marceau, S., Glé, P., Guéguen-Minerbe, M., Gourlay, E., Moscardelli, S., Nour, I. and Amziane, S. (2017). Influence of Accelerated Aging on the Properties of Hemp Concretes. Construction and Building Materials, 139, 524-530. doi:10.1016/j.conbuildmat.2016.11.129.

Margutti, M. and Pennati, A. (2018) Definition ofmethods for the control of qualityand for the correct laying and management of hempcrete blocks, MSc Thesis, Politecnico di Milano, Milan, Italy.

Murphy, R. J. and Norton, A. (2008). Life Cycle Assessments of Natural Fibre Insulation Materials Final Report. II th

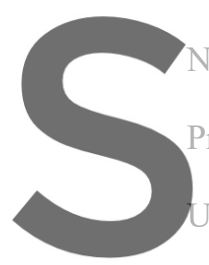
International Conferen

ordby, A.S. and Shea, Exchanges and Hygroth

\section{Pretot, S., Collet, F. and Grate} Thickness and Coating NI/TS 11300-1 (2008) elements. Assessment
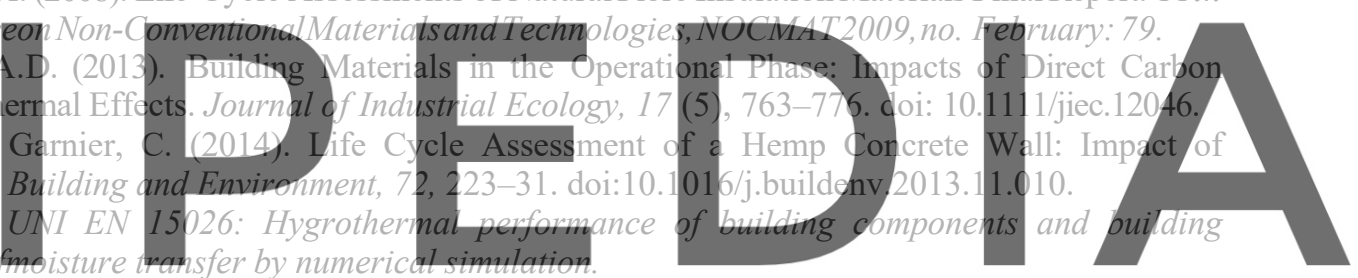

UNI/TS 11300-1 (2013). UNI EN ISO 13788: Hygrothermal performance of building components and building

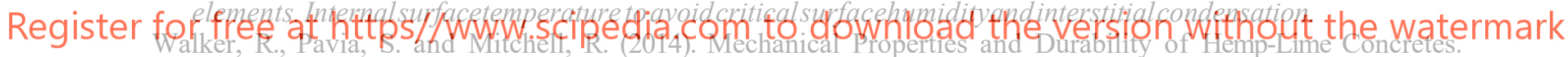
Construction and Building Materials, 61, 340-348. doi:10.1016/j.conbuildmat.2014.02.065.

Zampori, L., Dotelli, G. and Vernelli, V. (2013). Life Cycle Assessment of Hemp Cultivation and Use ofHemp- Based Thermal Insulator Materials in Buildings. Environmental Science and Technology, 47 (13), 7413 - 20. doi:10.1021/es401326a. 